\title{
The Effect of Sumatriptan in Ischemic Conditions in the Rat Heart
}

\section{Sumatriptanın Sıçan Kalbinde İskemik Koşullardaki Etkisi}

\author{
(D) Hande Özge ALTUNKAYNAK-ÇAMCA, (D) Müge TECDER-ÜNAL, (D) Meral TUNCER* \\ Bașkent University, Faculty of Medicine, Department of Pharmacology, Ankara, Turkey
}

\begin{abstract}
Objectives: The aim of this study was to investigate the effect of SUM on IR-induced injury in rat heart and its effect on IPC-induced protection. Materials and Methods: The rats were randomly divided into four groups: IR, SUM-IR, IPC, and SUM-IPC. The mean arterial blood pressure and heart rate were recorded to calculate PRP. Standard limb lead 2 ECG were recorded to evaluate arrhythmia parameters.

Results: The PRP values in the SUM-IPC group were significantly lower than in the SUM-IR group at the beginning of reperfusion ( $p<0.05$ ). The incidence of VT in the IPC, SUM-IR, and SUM-IPC groups was significantly lower than in the IR group ( $p<0.05)$. VF was only observed in the IR group.

Conclusion: SUM protects the heart against IR injury but is not as protective as IPC alone. Although SUM diminishes IPC-induced protection against VT, the preventive effect of SUM against VF may be predictive for cardioprotection in ischemic conditions.
\end{abstract}

Key words: Sumatriptan, heart, ischemia and reperfusion, ischemic preconditioning, arrhythmia

Öz

Amaç: Bu çalıșmanın amacı, SUM'un, IR'nin sıçanlarda neden olduğu kardiyak hasar ve IPC'nin oluşturduğu koruyuculuk üzerine etkisini incelemektir. Gereç ve Yöntemler: Sıçanlar rastgele olarak; IR, SUM-IR, IPC ve SUM-IPC gruplarına bölündü. Ortalama arteriyel kan basıncı ve kalp atım hızı, basınç hız ürününü (PRP) hesaplamak için kaydedildi. Aritmi parametrelerini değerlendirmek için standart EKG'ler kaydedildi.

Bulgular: SUM-IPC grubundaki PRP değerleri, SUM-IR grubundakilerden reperfüzyon bașlangıcında anlamlı olarak daha düșüktü (p<0.05). IPC, SUM-IR ve SUM-IPC gruplarındaki VT insidansı, IR grubundakinden anlamlı olarak daha düşüktü ( $p<0.05$ ). VF sadece IR grubunda gözlendi.

Sonuç: IPC'nin koruyucu etkisi kadar olmasa da, sumatriptan'ın kalbi IR hasarına karşı koruduğu gözlenmiştir. SUM VT'ye karşı IPC'nin oluşturduğu koruyuculuğu kısmen azaltsa da, VF'ye karşı önleyici etkisi iskemik koşullarda kalp için koruyucu olabilir.

Anahtar kelimeler: Sumatriptan, kalp, iskemi ve reperfüzyon, iskemik ön koşullama, aritmi

\section{INTRODUCTION}

5-hydroxytryptamine (5-HT; serotonin) has physiologic and pathophysiologic importance due to its effects on the periphery and the central nervous system. In this regard, regulation of the cardiovascular system by 5 -HT could result in complex effects such as hypotension/hypertension, vasodilatation/ vasoconstriction, and bradycardia/tachycardia, primarily depending on which 5 -HT receptors are involved. ${ }^{2}$ Sumatriptan (SUM), a $5-\mathrm{HT}_{1 \mathrm{~B} / 1 \mathrm{D}}$ receptor agonist, was the prototype of triptans used for the acute treatment of acute migraine attacks. ${ }^{3,4}$ Its therapeutic effect is closely linked with vasoconstriction of cranial blood vessels by the drug. ${ }^{5}$ Although SUM is generally well tolerated in the acute treatment of migraine attacks, some chest symptoms (i.e. chest pressure, tightness, and pain) mimicking angina pectoris and even myocardial infarction and fatal arrhythmia have been reported after the use of SUM.3,4,6-8 This could be related to the extracranial contractile effects of SUM including coronary vasoconstriction both in vivo and in vitro. 9.10 This effect is thought to be predominantly mediated by the agonistic activity of SUM at 5- $\mathrm{HT}_{1 \mathrm{~B}}$ receptors. ${ }^{6}$ Myocardial ischemia occurs when coronary blood supply to the myocardium is reduced (low-flow or no-flow ischemia), or relative to increased tissue demand (demand ischemia). ${ }^{11}$ Reperfusion, that is, the re-

*Correspondence: E-mail: mtuncer@baskent.edu.tr, Phone: +90 3122466683 ORCID-ID: orcid.org/0000-0003-3360-5092

Received: 07.09.2017, Accepted: 02.11.2017

๑Turk J Pharm Sci, Published by Galenos Publishing House. 
admission of oxygen and metabolic substrates together with washout of ischemic metabolites is necessary for the viability of ischemic myocardium. However, reperfusion could also have deleterious effects on ischemic myocardium, the process termed as "reperfusion injury".11 Therefore, protection from cardiac ischemia/reperfusion (IR) injury including arrhythmias, myocardial infarction, and contractile dysfunction has been the focus of intense research. Such a cardioprotective intervention is known as ischemic preconditioning (IPC), which applies brief non-lethal IR cycles before sustained ischemia of myocardium.1

Previous works suggested that the pressure rate product (PRP) could be an indirect index of myocardial oxygen consumption. ${ }^{12,13}$ It has been demonstrated that the tachycardia induced by positive inotropic agents including digitalis glycosides and ouabain enhanced myocardial oxygen consumption. ${ }^{14}$ As myocardial oxygen consumption increases, the heart rate (HR) is increased, and finally it negatively affects the cardiac function. ${ }^{14}$

There are some previous findings showing that SUM can induce an exacerbation of regional myocardial ischemia injury concomitant with a reduction in coronary blood flow. ${ }^{9}$ To the best of our knowledge, no studies have evaluated the effect of SUM on IPC-induced protection. Therefore, we aimed to investigate the effects of SUM in ischemic conditions in rats subjected to IR.

\section{MATERIALS AND METHODS}

\section{Animals}

The study was approved by Başkent University Ethics Committee for Experimental Research on Animals (project no: DA11/11, protocol number: 2011/21, date: 21.03.2011). Twenty male Wistar albino rats (250-350 g) were used in this study. The rats were housed in cages at room temperature $21 \pm 1^{\circ} \mathrm{C}$, under 12/12-hour light/dark cycles and were allowed access to standard laboratory diet and tap water ad libitum.

\section{Surgical procedures}

The rats were anesthetized using a ketamine/xylazine mixture (60/10 $\mathrm{mg} / \mathrm{kg}$, i.p.). The body temperature of the rats was measured using a rectal probe and maintained at $37 \pm 1^{\circ} \mathrm{C}$ with a lamp. Tracheotomy was performed to the anesthetized rats for mechanical ventilation through an animal ventilator (Rodent Ventilator 7025 UgoBasile, Italy, 5 mL/100 g, 34 pulse/min room air). A standard limb lead 2 electrocardiogram (ECG) and HR were continuously monitored and recorded throughout the experiments, using an ECG (100B; Biopac. System Inc., US) and a computerized data acquisition system. The right jugular vein and left carotid artery were cannulated for administration of SUM (3 mg/kg, i.v., bolus injection) and mean arterial pressure monitoring, respectively. The mean arterial blood pressure (MABP) and body temperature were also continuously monitored and recorded throughout the experiment using the same data acquisition system. Before the IR induction procedures, a left thoracotomy was performed through the fourth and fifth intercostal space, the pericardium was incised, and the heart was gently exteriorized. Afterwards, ischemia was induced by occlusion of the left anterior descending artery, close to its origin. Successful occlusion and ischemia were confirmed by a pronounced decrease in arterial pressure and ECG alteration. At the end of the study, the rats were sacrificed with a highdose anesthetic.

\section{Experimental protocols}

The dose of SUM ( $3 \mathrm{mg} / \mathrm{kg}$ ) was selected based on previously published studies. ${ }^{15,16}$

The rats were randomly divided into the groups as follows ( $n=5$ / group): IR group: following a stabilization period of $30 \mathrm{~min}$, the rats were subjected to $10 \mathrm{~min}$ of ischemia followed by $10 \mathrm{~min}$ of reperfusion (Figure 1 ).

SUM-IR group: following a stabilization period of $10 \mathrm{~min}$, a bolus SUM injection ( $3 \mathrm{mg} / \mathrm{kg}$ ) was administered. $20 \mathrm{~min}$ after the SUM injection, the rats were subjected to $10 \mathrm{~min}$ of ischemia followed by 10 min of reperfusion (Figure 1).

IPC group: Following a stabilization period of $10-$ min, IPC was applied by 2 cycles of 5 -min ischemia/5-min reperfusion. ${ }^{17}$ Afterwards, the rats were subjected to $10 \mathrm{~min}$ of ischemia followed by $10 \mathrm{~min}$ of reperfusion (Figure 1).

SUM-IPC group: Following a stabilization period of $10 \mathrm{~min}$, a bolus SUM injection ( $3 \mathrm{mg} / \mathrm{kg}$ ) was performed and immediately after IPC was applied by 2 cycles of 5 -min ischemia/5-min reperfusion. Afterwards, the rats were subjected to $10 \mathrm{~min}$ of ischemia followed by $10 \mathrm{~min}$ of reperfusion (Figure 1).

\section{Measured and calculated parameters}

Hemodynamic variables (MABP, HR) were monitored and recorded to calculate rate pressure product $(P R P=M A B P \times H R /$ 1000) as an indirect index of myocardial oxygen consumption.12,13 PRP was calculated after the surgical procedure (baseline), before and at the end of ischemia, at the beginning and end of the reperfusion.

The arrhythmia parameters were also evaluated from the ECG recordings of the rats in accordance with the Lambeth

\begin{tabular}{|c|c|c|c|c|}
\hline IR & $\begin{array}{c}\text { BASELINE } \\
10 \mathrm{~min}\end{array}$ & $20 \mathrm{~min}$ & $\begin{array}{l}\text { ISCHEMIA } \\
10 \mathrm{~min}\end{array}$ & $\begin{array}{c}\text { REPERFUSION } \\
10 \mathrm{~min}\end{array}$ \\
\hline \multicolumn{5}{|c|}{$\begin{array}{c}\text { Sumatriptan } \\
3 \mathrm{mg} / \mathrm{kg}\end{array}$} \\
\hline SUM-IR & $\begin{array}{c}\text { BASELINE } \\
10 \mathrm{~min}\end{array}$ & $20 \mathrm{~min}$ & $\begin{array}{l}\text { ISCHEMIA } \\
10 \mathrm{~min}\end{array}$ & $\begin{array}{c}\text { REPERFUSION } \\
10 \mathrm{~min}\end{array}$ \\
\hline
\end{tabular}

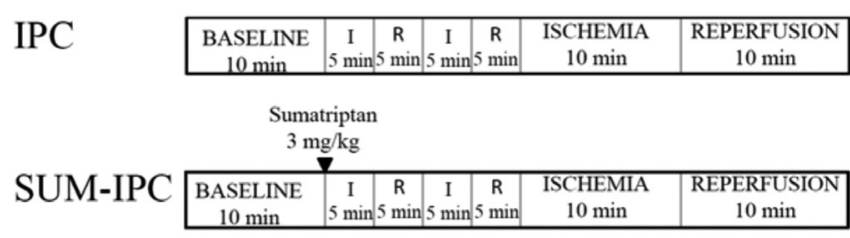

Figure 1. Schematic diagram illustrating experimental protocol IR: Ischemia/reperfusion, SUM: Sumatriptan, IPC: Ischemic preconditioning, I: Ischemia, R: Reperfusion 
conventions at the end of the experimental protocols. ${ }^{18}$ The incidence of ventricular tachycardia (VT) and ventricular fibrillation (VF) were determined in each group.

\section{Statistical analysis}

Data are expressed as mean \pm standard error and the percentage of the incidence. Data of PRP were analyzed using one-way analysis of variance followed by the Bonferroni post-hoc test (for selected columns). Incidence of arrhythmia was evaluated using Fisher's exact test. All analyses were conducted using the GraphPad Prism (version 5.00 for Windows, GraphPad Software, San Diego California USA). P values of $<0.05$ were considered statistically significant.

\section{Drugs}

SUM succinate (GlaxoSmithKline, Turkey) was dissolved in saline.

\section{RESULTS}

PRP values, calculated for myocardial oxygen consumption, during experimental protocols are shown in Figures 2A-E. PRP values at both baseline and before the ischemia did not significantly differ between the groups. However, the PRP value in the SUM-IPC group was significantly lower than that of the SUM-IR group at the beginning of the reperfusion (Figure $2 \mathrm{D}, \mathrm{p}(0.05)$. Although there was a tendency for a decrease in the PRP value of the SUM-IPC group when compared with the IPC group, the difference was not significant at the end of the reperfusion (Figure $2 \mathrm{E}$ ).

SUM produced a significant reduction in the incidence of $\mathrm{VT}$ in the SUM-IR and SUM-IPC groups (40\%). In the IPC group, the incidence of VT was significantly lower than in the SUM-IPC group (10\% and $40 \%$, respectively, $\mathrm{p}<0.05$ ) (Figure $3 \mathrm{~A}$ ).

VF was only observed in the IR group and the incidence was $80 \%$. The administration of SUM both in the SUM-IR and in the SUM-IPC groups inhibited VF, similar to the IPC group alone (Figure 3B).

\section{DISCUSSION}

We investigated the effect of SUM in myocardial ischemic conditions in anesthetized rats. Our findings showed that SUM was cardioprotective against IR injury, but not as protective as IPC alone. The administration of SUM before IPC resulted in the reduction of myocardial oxygen consumption as shown by decreased PRP at the beginning of reperfusion. Despite that, it provided no additional protection from VT induced by IPC. In addition, administration of SUM alone to the rats subjected to IR in the SUM-IR group produced a reduction in the incidence of VT compared with the IR group. Among these groups, VF was only observed in the IR group. It appears that SUM is effective in preventing VF, similar to that of IPC.

IPC has been shown to decrease ischemia-induced arrhythmia in normal hearts. ${ }^{19}$ Consistent with these findings, we demonstrated that IPC conferred a marked reduction in arrhythmogenesis as shown by the reduction in the incidence
$\mathbf{A}$

B
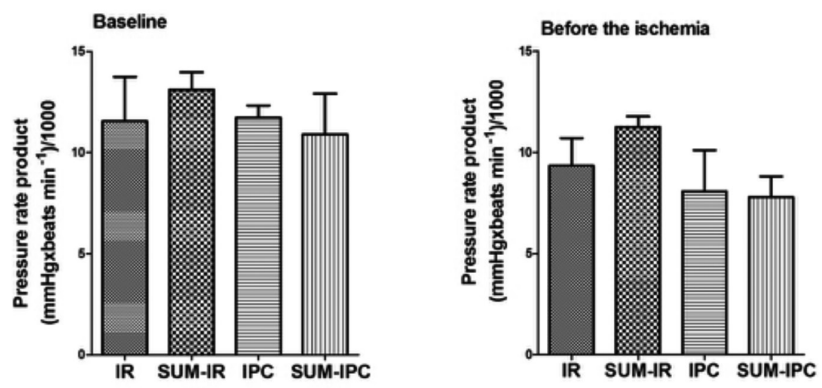

C

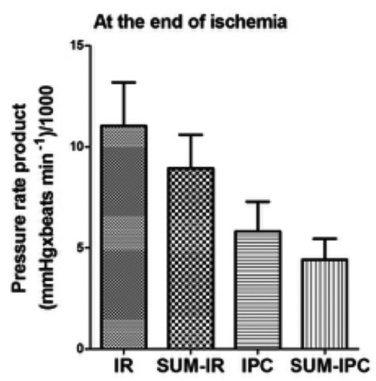

D

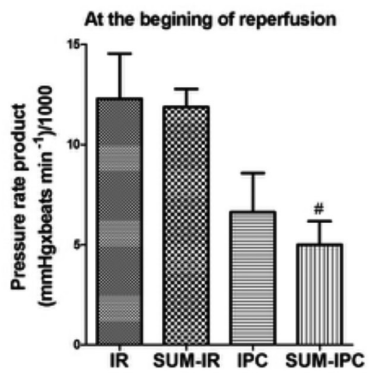

$\mathbf{E}$

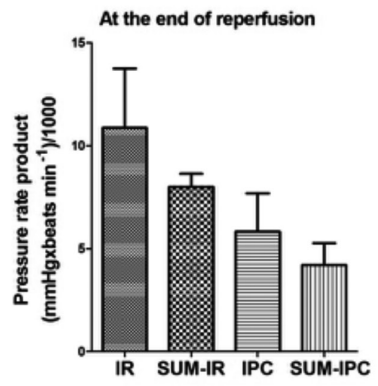

Figure 2. PRP values for baseline (A), before the ischemia (B), at the end of ischemia (C), at the beginning of the reperfusion (D) and at the end of reperfusion (E) in IR, SUM-IR, IPC and SUM-IPC groups

IR: Ischemia/reperfusion, SUM: Sumatriptan, IPC: Ischemic preconditioning, \#p<0.05 vs SUM-IR

A

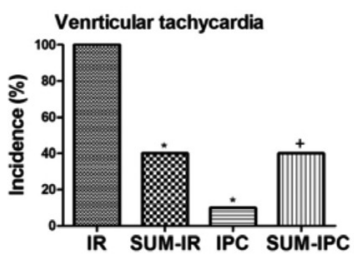

B

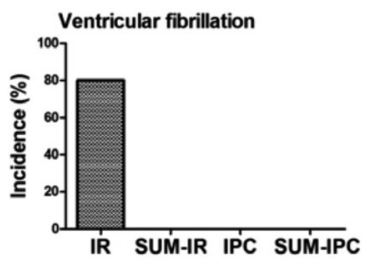

Figure 3. The incidence of ventricular tachycardia and ventricular fibrillation in IR, SUM-IR, IPC and SUM-IPC groups

IR: Ischemia-reperfusion, SUM: Sumatriptan, IPC: Ischemic preconditioning, ${ }^{*} p<0.05$ vs IR, ${ }^{+} p<0.05$ vs IPC

of VT and prevention of VF. Similarly, administration of SUM alone to the rats subjected to IR decreased the incidence of 
VT. However, it diminished IPC-induced protection against VT when applied before IPC. Interestingly, at the beginning of reperfusion, the myocardial oxygen consumption in the SUMIPC group was lower than in the SUM-IR group. However, it provide no additional protection against VT in the SUM-IPC group.

Taken together, one might think that SUM could interfere with the common mechanisms of IPC. On the other hand, it may also mimic the IPC by leading to coronary vasoconstriction. Support for this conclusion comes from a number of studies in which SUM-induced contractions of coronary arteries have been shown both in vivo and in vitro.,10 Therefore, SUM might interfere with the common mechanisms of IPC. The majority of in vivo human angiographic and positron emission tomography studies with SUM reported very slight to no coronary artery constriction or reduction in myocardial perfusion with no association with ECG changes or anginal symptoms. ${ }^{20-23}$ However, it was noticed that even modest epicardial coronary constriction could be sufficient to provoke an ischemic event in patients with coronary artery disease. ${ }^{23}$ It has also been reported that SUM provoked coronary vasospasm in patients with variant angina but not in control subjects, suggesting the coronary constrictory effect of SUM may be more notable in patients with ischemic heart disease. ${ }^{24}$ For this reason, SUM should be used with caution in these kinds of patients. Additionally the physicians must be aware when they prescribe sumatriptan for migraine attacks in patients with any cardiovascular symptoms.

Some mechanisms of IPC are associated with the release of substances such as adenosine, bradykinin, endothelin, and endorphins. ${ }^{25}$ Some alternative protective mechanisms independent from signal transduction cascades mediated by antioxidant and anti-inflammatory mechanisms are also involved in IPC-induced protection. ${ }^{25}$ Additionally, IPC exerts protection through a reduction of myocardial energy demand during ischemia. ${ }^{26}$ In the present study, we demonstrated that myocardial oxygen consumption was decreased both in the IPC and SUM-IPC groups. Furthermore, the myocardial oxygen consumption in the SUM-IPC group was significantly lower than SUM-IR at the beginning of reperfusion. Despite that, the protective effect against VT was similar in both groups, but less than in the IPC group. Taken together, these findings exclude the possibility that neither IPC nor SUM protects the heart against VT by altering oxygen consumption of the myocardium. It could be thought that mechanism other than the decrease in oxygen consumption might contribute to this protection.

In our study, the duration of ischemia was sufficient to observe ischemia-induced arrythmias; however, a longer duration is necessary to see ischemia-induced infarct areas in the heart. It would be interesting to investigate whether SUM would be able to decrease the size of infarct area during longer durations of ischemia. In addition, the lack of molecular mechanisms underlying the effects of SUM concerning IPC in this protection is a limitation of the study. We hope that this study will lead to future research with SUM in different ischemic conditions.

\section{CONCLUSIONS}

In conclusion, the results of the study show that bolus injections of SUM alone protects the rat heart against IR injury by decreasing the incidence of arrhythmia. SUM is cardioprotective against arrhythmias in rats subjected to IR injury but not as protective as in IPC. However, the preventive effect of SUM against VF may be predictive for cardioprotection in ischemic conditions. Further studies are needed to elucidate which mechanisms of IPC interfere with SUM.

\section{ACKNOWLEDGEMENTS}

This study was supported by Başkent University Research Fund (DA 11/11). We thank GlaxoSmithKline (Turkey) for their generous gift of SUM and Seda Cal and Erkan Ermis (biologists of the Pharmacology Department); Adem Kurtçuoğlu and Sezai Kolçuk (Experimental Animals Production and Research Center Unit) for their technical assistance, and Yasemin Özerdem, Güldeniz Uzar, İdil Bahar Abdulazizoğlu, Cemre Çavuşoğlu, Gökçe Yağmur Efendi, and Hamit Koç (undergraduate students of Başkent University Medical Faculty) for observing as part of their education.

Conflict of Interest: No conflict of interest was declared by the authors.

\section{REFERENCES}

1. Ramage AG, Villalón CM. 5-hydroxytryptamine and cardiovascular regulation. Trends Pharmacol Sci. 2008;29:472-481.

2. Villalón CM, De Vries P, Saxena PR. Serotonin receptors as cardiovascular targets. Drug Discovery Today. 1997;2:294-300.

3. Weiss O. Ueber die Wirkungen von Blutserum-Injectionen ins Blut. Archiv für die Gesamte Physiologie des Menschen und der Thiere. 1896;65:215-230.

4. Hoyer D, Clarke DE, Fozard JR, Hartig PR, Martin GR, Mylecharane EJ, Saxena PR, Humphrey PP. International Union of Pharmacology classification of receptors for 5-hydroxytryptamine (Serotonin). Pharmacol Rev. 1994;46:157-203.

5. Duquesnoy C, Mamet JP, Sumner D, Fuseau E. Comparative clinical pharmacokinetics of single doses of sumatriptan following subcutaneous, oral, rectal and intranasal administration. Eur J Pharm Sci. 1998;6:99-104.

6. Villalón CM, Centurión D. Cardiovascular responses produced by 5-hydroxytriptamine: a pharmacological update on the receptors/ mechanisms involved and therapeutic implications. Naunyn Schmiedebergs Arch Pharmacol. 2007;376:45-63.

7. Mueller L, Gallagher RM, Ciervo CA. Vasospasm-induced myocardial infarction with sumatriptan. Headache. 1996;36:329-331.

8. Laine K, Raasakka T, Mäntynen J, Saukko P. Fatal cardiac arrhythmia after oral sumatriptan. Headache. 1999;39:511-512.

9. Lynch JJ Jr, Stump GL, Kane SA, Regan CP. The prototype serotonin 5-HT 1B/1D agonist sumatriptan increases the severity of myocardial ischemia during atrial pacing in dogs with coronary artery stenosis. J Cardiovasc Pharmacol. 2009;53:474-479.

10. Kemp BK, Cocks TM. Effects of U46619 on contractions to 5-HT, sumatriptan and methysergide in canine coronary artery and saphenous vein in vitro. Br J Pharmacol. 1995;116:2183-2190. 
11. Ferdinandy P, Schulz R, Baxter GF. Interaction of cardiovascular risk factors with myocardial ischemia/reperfusion injury, preconditioning, and postconditioning. Pharmacol Rev. 2007;59:418-458.

12. Krzeminski TF, Mitrega K, Porc M, Zorniak M, Ryszka F, Ostrowska Z, Kos-Kudła B. Differential action of two prolactin isoforms on ischemia and re-perfusion-induced arrhythmias in rats in vivo. J Endocrinol Invest. 2011;34:206-215.

13. Baller D, Bretschneider HJ, Hellige G. A critical look at currently used indirect indices of myocardial oxygen consumption. Bas Res Cardiol. 1981;76:163-181.

14. Fawaz G, Tutunji B. Ouabain-induced ventricular tachycardia and its effect on the performance and metabolism of the dog heart. $\mathrm{Br} J$ Pharmacol Chemother. 1959;14:355-357.

15. Spokes RA, Middlefell VC. Simultaneous measurement of plasma protein extravasation and carotid vascular resistance in the rat. Eur J Pharmacol. 1995;281:75-79.

16. Johnson DE, Rollema H, Schmidt AW, McHarg AD. Serotonergic effects and extracellular brain levels of eletriptan, zolmitriptan and sumatriptan in rat brain. Eur J Pharmacol. 2001;425:203-210.

17. Ahmed LA, Salem HA, Attia AS, Agha AM. Comparative study of the cardioprotective effects of local and remote preconditioning in ischemia/ reperfusion injury. Life Sci. 2012;90:249-256.

18. Walker MJ, Curtis MJ, Hearse DJ, Campbell RW, Janse MJ, Yellon DM, Cobbe SM, Coker SJ, Harness JB, Harron DW, et al. The Lambeth Conventions: guidelines for the study of arrhythmias in ischaemia infarction, and reperfusion. Cardiovasc Res. 1988;22:447-455.
19. Ravingerová T, Matejíková J, Pancza D, Kolár F. Reduced susceptibility to ischemia-induced arrhythmias in the preconditioned rat heart is independent of PI3-kinase/Akt. Physiol Res. 2009;58:443-447.

20. Macintyre PD, Bhargava B, Hogg KJ, Gemmill JD, Hillis WS. The effect of i.v. sumatriptan, a selective 5-HT1-receptor agonist on central haemodynamics and the coronary circulation. $\mathrm{Br} \mathrm{J}$ Clin Pharmacol. 1992;34:541-546.

21. Macintyre PD, Bhargava B, Hogg KJ, Gemmill JD, Hillis WS. Effect of subcutaneous sumatriptan, a selective $5 \mathrm{HT} 1$ agonist, on the systemic, pulmonary, and coronary circulation. Circulation. 1993;87:401-405.

22. Newman CM, Starkey I, Buller N, Seabra-Gomes R, Kirby S, Hettiarachchi J, Cumberland D, Hillis WS. Effects of sumatriptan and eletriptan on diseased epicardial coronary arteries. Eur J Clin Pharmacol. 2005;61:733-742.

23. Lewis PJ, Barrington SF, Marsden PK, Maisey MN, Lewis LD. A study of the effects of sumatriptan on myocardial perfusion in healthy female migraineurs using $13 \mathrm{NH} 3$ positron emission tomography. Neurology. 1997;48:1542-1550.

24. Bax WA, Renzenbrink GJ, Van Heuven-Nolsen D, Thijssen EJ, Bos E, Saxena PR. 5-HT receptors mediating contractions of the isolated human coronary artery. Eur J Pharmacol. 1993;239:203-210.

25. Huffmyer J, Raphael J. Physiology and pharmacology of myocardial preconditioning and postconditioning. Semin Cardiothorac Vasc Anesth. 2009;13:5-18.

26. Murry CE, Richard VJ, Reimer KA, Jennings RB. Ischemic preconditioning slows energy metabolism and delays ultrastructural damage during a sustained ischemic episode. Circ Res. 1990;66:913-931. 